\title{
Correction to: Delineating forest stands from grid data
}

Timo Pukkala

\section{Correction to: Forest Ecosystems}

$$
\text { https://doi.org/10.1186/s40663-020-00221-8 }
$$

In the original publication of this article (Pukkala, 2020) Fig. 6 is not correct, the correct figure is as below. The error in this Correction and low quality Fig. 4 and Fig. 5 have been updated in the original article and the caption of Fig. 5 was modified.
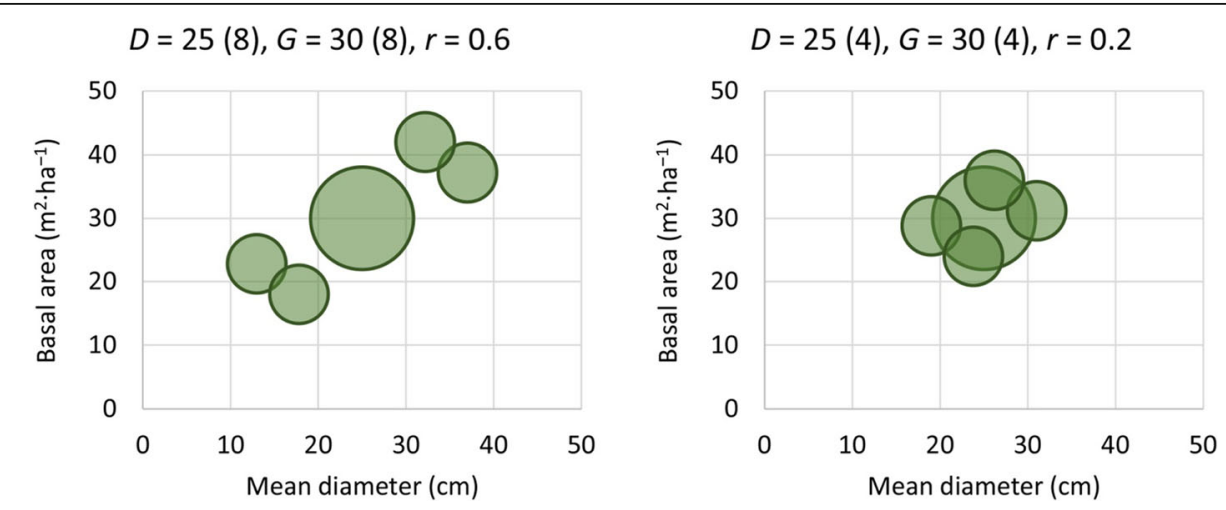

Fig. 6 Basal areas and mean diameters of the five virtual stands generated for a sub-stand based on the mean and standard deviation of stand basal area and mean diameter and their correlation. The size of the circle represents the relative area of each virtual stand, calculated from multinormal probability density function. In both cases, the average value of mean diameters of the cells that constitute the stand $(D)$ is $25 \mathrm{~cm}$ and the average stand basal area of the cells $(G)$ is $30 \mathrm{~m}^{2} \cdot \mathrm{ha}^{-1}$. The standard deviations (in brackets) are larger on the left-hand-side diagram and thecorrelation between basal area and mean diameter is stronger

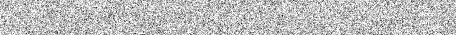

\section{Reference}

Pukkala T (2020) Delineating forest stands from grid data. Forest Ecosystems 7:13

https://doi.org/10.1186/s40663-020-00221-8

The original article can be found online at https://doi.org/10.1186/s40663020-00221-8

Correspondence: timo.pukkala@uef.fi

University of Eastern Finland, PO Box 111, 80101 Joensuu, Finland

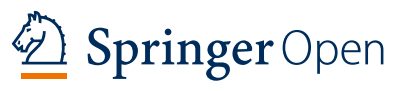

(อ) The Author(s). 2020 Open Access This article is licensed under a Creative Commons Attribution 4.0 International License, which permits use, sharing, adaptation, distribution and reproduction in any medium or format, as long as you give appropriate credit to the original author(s) and the source, provide a link to the Creative Commons licence, and indicate if changes were made. The images or other third party material in this article are included in the article's Creative Commons licence, unless indicated otherwise in a credit line to the material. If material is not included in the article's Creative Commons licence and your intended use is not permitted by statutory regulation or exceeds the permitted use, you will need to obtain permission directly from the copyright holder. To view a copy of this licence, visit http://creativecommons.org/licenses/by/4.0/. 